man unter energischen Reduktionsbedingungen und bei Anwendung relativ großer Tellurmengen (zirka 0,15 Proz.)

Die Analyse ergab, daß jene Gläser Telluride, bei Ueberschuß von Tellur also wahrscheinlich Polytelluride enthalten und daß dieselben nicht optisch leer sind. Die in diesen Gläsern anwesende disperse Phase hat einen gröBeren Dispersitätsgrad als in den andern noch zu erwähnenden mit Tellur gefärbten Gläsern von brauner oder blauer Farbe. Aus den Veränderungen der Konzentration der in diesen roten Gläsern enthaltenen Submikronen und ihrer Beziehung zur Intensität der Färbung konnte jedoch nicht festgestellt werden, dab diese Submikronen tatsächlich das Farbpigment bilden; es ist nicht unwahrscheinlich, daß es sich um eine kolloiddisperse Substanz handelt, die keinen direkten Einfluß auf die Färbung hat. Der im Ultramikroskope zu beobachtende Lichtkegel von blasser blauvioletter Farbe ist mit dem Ze i B'schen Objektiv $D^{*}$ schwer auflösbar. Die Auflösung erfolgt hingegen vollständig mit Hilfe der Zeiß'schen Homogenimmersion $1 / 12$ "; alle sichtbaren Submikronen sind von gleichem Aussehen. Das heißt aber, daß, wenn diese kolloid-disperse Substanz, wie es den Anschein hat, nicht das Pigment vorstellt, dieses letztere sich in einem noch höheren Dispersionsgrad, vielleicht sogar im molekular-dispersen Zustand befinden muf. Das Absorptionsspektrum derartig gefärbter Gläser ist identisch mit jenem der wässerigen Lösung des Kaliumpolytellurids und umfaßt wie dieses eine allgemeine $\mathrm{Ab}$ sorption des gesamten Teiles des Spektrums zwischen Orange bis einschlieblich zum Violett mit einem charakteristischen Maximum bei ungefähr $480-490 \mu \mu$.

Neben diesen Gläsern kann man mit Tellur (immer unter reduzierenden Schmelzbedingungen) bei bloßer Aenderung der Konzentration, ganz analog wie bei den Hydrosolen, verschieden gefärbte kolloide Lösungen erhalten, und zwar bei niedriger Konzentration des Tellurs eine braune, bei höherer eine stahlblaue; letztere Färbung ist durch Submikronen von größeren Dimensionen als jene, die die Braunfärbung bestimmen, bedingt.

Versuche, bleihaltige Gläser und Glasuren mit Tellur zu färben, waren — wie übrigens vorauszusehen war - vollständig negativ, da man ohne energische Reduktion nur durchsichtige farblose Gläser erhält, während es bei stattfindender Reduktion infolge der Entstehung von Bleitellurid und der Zersetzung des Bleiglases zur Bildung schwärzlicher Massen kommt.

Mit Zunahme des Dispersitätsgrades des Tellurs im Glase beobachtet man also analog dem Verhalten der Hydrosole, sogar noch deutlicher, einen Uebergang der Färbung von Blau zu Braun und Rot.

Dies ist in vollster Uebereinstimmung mit. dem Ostwald'schen Gesetz sowie eine schöne Bestätigung desselben, nach welchem „mit zunehmendem Dispersionsgrad der dispersen Phase das Absorptionsmaximum im Spektrum sich nach den kürzeren Wellen zu verschiebt“.

Mailand, den 4. Januar 1915.

Aus dem Privatlaboratorium
des Verfassers.

\title{
Die Einwirkung von Elektrolyten auf organische Abwässer.
}

\author{
Von Paul Rohland (Stuttgart). (Eingegangen am 5. Jaunar 1915.)
}

Kolloid veranlagte Silikate, natürliche wie Ton, Kaolin' ${ }^{1}$ ), Talk und künstliche wie Zement, Ultramarin usw. können durch Zusatz von bestimmten Elektrolyten zur raschen Sedimentation gebracht werden, z. B. Kaolinsuspensionen durch Zusatz von Hydroxylio ne $n$ in bestimmter Konzentration, Ultramarinund Zementsuspensionen durch Zusatz von verdünnten Lösungen von $\mathrm{Kalzi}$ m chlorid, Kalziumsulfat und Natriumchlorid.

1) Vg1. P. Rohl a nd, Die Einwirkung von Hydro$x$ vionen auf Kaolinsuspensionen. (Koll.-Zeitschr. 1912.)
Nur auf kolloid veranlagte Stoffe findet diese Einwirkung statt, weil sie in Berührung mit Wasser kolloide Substanzen, die Hydroxyde des Siliziums, Aluminiums, Magnesiums und Eisens bilden.

Berliner Blau ist kolloider Natur und gehört auch hierher.

Dagegen werden alle $\mathrm{kr}$ istalloide $\mathrm{n} \mathrm{Sub-}$ stanzen, gleichviel ob organischer oder anorganischer Natur, z. B. Bariumsulfat durch Zusatz von Elektrolyten nicht sedimentiert.

Es ist merkwürdig, daß di e Elektrolyte, die am stärksten auf die Sedimentation mancher 
kolloider und kolloid veranlagter Stoffe wirken, zugleich hygroskopisch sind, wie z. B. Chlorkalzium.

Die im Sinne des negativen Stromes wandernden kolloiden und kolloid veranlagten Teilchen treffen mit den positiv geladenen Kationen zusammen und werden mit zu Boden gerissen.

Die Einwirkung von Elektrolyten auf Wässer, die kolloide und kolloid veranlagte Stoffe enthalten, kann auch im Großen beobachtet werden.

Durch organische Abwässer, die solche Substanzen in großer Menge enthalten, verunreinigte Bäche oder Flüsse können durch Zusatz von Elektrolyten, durch rasche Sedimentation dieser Substanzen geklärt werden.

Ist ein Vorfluter mit organ ischen $\mathrm{Ab}$ wässern, städtischen Abwässern oder Abwässern, die aus Rohrzuckerfabriken, Brauereien, Lederfabriken usw. stark überlastet, so kann durch Einleitung eines anorganische n Abwassers, das viel Elektrolyte enthält, z. B. eines Metallindustriewerkes, eines Kaliwerkes Klärung des Wassers des Vorfluters hierdurch auf dem oben angegebenen Wege erzielt werden.

Die Endlaugen der Kaliwerke enthalten nur Elektrolyte $^{2}$ ): $\mathrm{MgCl}_{2}$ 29,5 Proz.

$\begin{array}{ll}\mathrm{NaCl} & 0,95 " \\ \mathrm{KCl} & 1,25 " \\ \mathrm{Mg} \mathrm{Br}_{2} & 0,30 " \\ \mathrm{Mg} \mathrm{SO} & 2,22,\end{array}$

Auch die Mikroorganismen werden hierdurch abgetötet.

Die Zuleitung elektrolythaltiger Abwässer in einen mit organischen, kolloide und kolloid veranlagte Stoffe enthaltenden Abwässern behafteten Fluß kann als Vorbeugungsmittel gegen die durch Ueberladung mit organischen Substanzen bedingten Schäden angesehen werden.

Allerdings hat die sedimentierende und klärende Wirkung dieser Elektrolyte einen be-

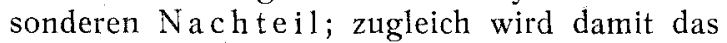
$\mathrm{Pl}$ a nkton, das animalische und vegetabilische Nahrungsmittel der Fische, das ebenfalls zum großen Teil kolloider Natur ist, sedimentiert und so aus dem Flußwasser entfernt.

So läßt sich die Einwirkung von Elektrolyten auf Abwässer, die kolloide und kolloid veranlagte Stoffe in größerer Menge enthalten, zu deren Klärung anwenden. Solche $\mathrm{Ab}$ wässer sind außer den städtischen Abwässern die der Textilwerke, Papierfabriken, Lederfabriken, Brennereien, Brauereien, Molkereien, Preßhefefabriken, Rohzuckerfabriken und Raf-

2) Die Kaliindustrie und die Kaliabwässerfrage. finerien usw. Diese sind im wesentlichen eine Kombination von Kolloidsuspensionen und Kolloidemulsionen. Durch Zusatz von Elektrolyten kann aber nur eine Klärung des Abwassers erzielt werden, keine Reinigung.

Die Begriffe der Klärung und Reinigung eines Abwassers sind streng auseinander zu halten. Die Klärung soll die kolloid veranlagten Stoffe, die festen kleinen Bestandteile, die Schwebestoffe, beseitigen, während die Reinigung alle schädlichen gelösten Substanzen, Farbstoffe, Fette, Oele usw. entfernen soll.

Zunächst kann durch einen Elektrolytzusatz eine rein mechanische Sedimentierung der Schwebestoffe im Abwasser erzielt werden; enthält z.B. ein Abwasser außer diesen $\mathrm{SO}_{4}$ "-Ionen und erfolgt ein Zusatz von $\mathrm{Ca}$ "-lonen, so reißt das sich bildende und gefällt werdende $\mathrm{Kal}$ ziumsulfat auch die Schwebestoffe mit zu Boden.

Auch der umgekehrte Fall ist möglich, daß $\mathrm{Ca}$ "-Ionen in dem Abwasser vorhanden sind, die durch Zusatz von $\mathrm{SO}_{4}$ "-Ionen zur Bildung von Kalziumsulfat führen. Bei solchen mechanischen Klärungen ist also eine genaue Kenntnis der Bestandteile des Abwassers notwendig.

Auf kolloidchemischem Wege erfolgt die Klärung folgendermaßen: die in organischen städtischen und den oben genannten Fabrikabwässern enthaltenen schädlichen Bestandteile sind als kolloid gelöste und kolloid veranlagte Stoffe elektronegativ. Tritt nun zu diesen ein elektrisch positives Anion bestimmter Art wie $\mathrm{Ca}{ }^{*}, \mathrm{Fe}^{\cdots}$, Al ${ }^{\cdots}$ Salze, die schon Justus v. Liebig vorgeschlagen hat, so findet eine Koagulation und Sedimentation statt; es entsteht eine lebhafte Bewegung in dem Abwasser, welche die Schwebestoffe von unten nach oben und in umgekehrter Richtung treibt; sie ballen sich zu größeren Flocken zusammen und sinken rasch zu Boden.

Ein solcher Elektrolytzusatz ist aber nur da wirksam, wo Kolloide, mitunter sogar ganz bestimmte Kolloide, in dem Abwasser enthalten sind. Eine Kenntnis der Menge der Kolloide $^{3}$ ) und ihrer Art ist also nötig.

Denn es kann vorkommen, daß bei Fabrikabwässern, die Kolloide enthalten, auf Zusatz von $\mathrm{Ca} \cdot$ - oder Al'-Ionen trotzdem die Koagulation und somit die Klärung a usbleibt, da diese lonen erstere nicht herbeizuführen vermögen.

3) Vgl. P. Rohland, Die quantitative Bestimmung der Kolloide in den Abwässern. (Koll.-Zeitschr. 1913.) 
Daher ist es vorgekommen, daß der von den Behörden empfohlene Kalk $z$ usat $z$ zum Abwasser nicht nur vollständig unwirksam war, sondern sogar, wenn er im Ueberschuß zugesetzt wurde und in die Vorfluter gelangte, schädlich wirkte, indem er sein Wasser verhärtete. Es läßt sich jetzt vermuten, daß in einem Abwasser, das elektronegative Kolloide enthält, ein elektropositives Kation eine sedimentierende und koagulierende Wirkung ausübt, während in einem Abwasser, das elektropositive Kolloide führt, ein elektronegatives Anion, z. B. das Hydroxylion, die gleiche Wirkung ausübt.

In einigen Fällen scheint auch das nicht dissoziierte Kalzium-Hydroxydmolekül eine Rolle dabei zu spielen.

\section{Referate.}

\section{Arbeiten über Biochemie und Physiologie.}

Hirschfeld, L., und R. Klingner, Beiträge zur Physiologie der Blutgerinnung. (Biochem. Zeitschr. 68, 163, 1915.)

Eine wässerige Emulsion von ölsaurem Natrium kann bei der Blutgerinnung das Cytozym sehr gut ersetzen. Die Seife verhält sich auch in anderen Beziehungen wie die natürlichen Cytozyme (Plättchenoder Organextrakte). So werden letztere beim Erhitzen auf $56^{\circ}$ größtenteils zerstört. Dies gilt auch für die Wirksamkeit der Seife als Cytozym, wenn sie einem Serum zugesetzt wird. In rein wässeriger Lösung sind dagegen die natürlichen Extraktcytozyme so wie die Seifen hitzebeständig. Durch Spaltung eines cytozymhaltigen Serums in die Globulin- tund Albuminfraktion wird das Cytozym fast vollständig mit der Globulinfraktion ausgefälit. Das gleiche geschieht mit der zugesetzten Seife. R. E. Lg.

\section{Arbeiten über Medizin und Pharmakologie.}

Krauss, F., Ueber die Wassermannsche Reaktion im normalen Menschenserum. (Biochem. Zeitschr. 68, 48, 1915.)

Wiederholt sind Versuche gemacht worden, die Wirkungsweise der komplementbindenden Stoffe im luetischen Serum dadurch zu erklären, daß dieses Serum gegenüber dem normalen in kolloider Beziehung verändert sei. Die Möglichkeit, ein normales Serum im Reagensglas so zu verändern, daf es die Wassermannsche Reaktion gibt, sollte diese Anschaunngen stützen. (Vgl. H. Bechhold, Die Kolloide in Biol. u. Med. p. 192.) Die Verfasserin bestreitet, daß durch diese Einflüsse dem Serum neue Eigenschaften verliehen werden. Sie weist nach, daß auch schon im normalen Serum die komplementbindenden Stoffe vorhanden sind. Nur sind sie in diesem irgendwie verdeckt. Die kolloidchemische Veränderung beseitigt nur diese Hemmung. Im luetischen Serum soll aber der Gehalt an komplementbindenden Stoffen tatsächlich erhoht sein.

$$
\text { R. E. L.g. }
$$

Mc Kelvie, J. P., und J. Rosenbloom, Ueber den Cholesterinstoffwechsel in einem Falle von angeborener hämolytischer Gelbsucht mit Splenomegalie. (Biochem. Zeitschr. 68, 78, 1915.)

Vollständig von Serum befreite tote Blutkörperchen erleiden bekanntlich keine Hämolyse durch Kobragift, Tetanustoxin, Solanin, Saponin usw., während bei Anwesenheit von Serum die Auflösung erfolgt. Es zeigt sich nun, daß Lezithin wie Blutserum wirkt. Choles- terinzusatz wirkt dagegen umgekehrt hemmend. Setzt man nämlich einer Suspension von roten Blutkörperchen mit Lezithin und gewissen auflösenden Substanzen Cholesterin hinzu, so bleibt die Hämolyse aus. Daraus erklärt sich der im Titel genannte Zusammenhang

R. E. Lg.

\section{Arbeiten über Mineralogie und Agrikulturchemie.}

Li es e gang, R. E., Pseudostalaktiten und Verwandtes. (Geol. Rundschau 5, 241, 1914.)

Die bekannten „Silikat-Gewächse", welche man beim Einwerfen von festem Eisenchlorid, Eisenvitriol usw. in etwas verdïnnte Wasserglaslösungen erhält, werden verglichen mit eigenartigen Achaten. Bisher waren die letzteren als Stalaktiten betrachtet worden. Dagegen sprach jedoch der Umstand, daß sie oft auffallend von der Richtung abwichen, welche man als die von der Schwerkraft bestimmte bezeichnen müßte. Unerklärt bliebe dabei auch das Fehlen der Stalagmiten in den betreffenden Melaphyrgeoden, und ferner der stets eisenhaltige Kern der Gebilde. Es wird angenommen, daß es sich um natürliche Silikatgewächse handelt. - Während die neuere Theorie der Festungsachate annimmt, daß die Melaphymandelräume mit einem Kieselsäuregel gefüllt waren, und daß hierin das Eisen rhythmisch gefällt wurde, muß man in diesen Fällen das Vorhandensein einer wasserglasähnlichen Silikatlosung annehmen, in welches eine lösliche Eisenverbindung eindrang. Die Kieselsäure kristallisierte nachträglich hauptsächlich zu Chalzedon. In seltenen Fällen ist das Material, welches die feinen Brauneisenröhren umgibt, Edelopal ; so $z$. B. bei einem Vorkommen von Czerwenitza in Ungarn. Hier scheint das lösliche Eisen durch Oxydation von Pyrit entstanden zu sein. - Natürlich ist Vorsicht wegen einer Verwechselung mit echten Stalaktiten notwendig. Es wäre angebracht, nach einem Namen für diese Gebilde $z u$ suchen, welcher nicht nur daran crinnert, daß man sich bei der fräheren Erklärung im Irrtum befand.

R. F. Lg.

Meigen, W., und H. G. Schering, Chemische Untersuchungen über LöB und Lehm aus der oberrheinischen Tiefebene. (Mitt. d. Großh. Bad. Geolog. Landesanstalt 7, 643, 1914.)

Der LöB besteht hauptsächlich aus äußerst feinen Quarz- und Feldspatsplittern. Kohlensaurer Kalk überzieht und verkittet dieselben locker. Der Gehalt an letzterem wechselt sehr. Er übersteigt aber nicht 40 Proz. 